\title{
Asynchronous DNA replication detected by fluorescence in situ hybridisation as a possible indicator of genetic damage in human lymphocytes
}

\author{
A. BRÁS ${ }^{1}$, C.Z. COTRIM ${ }^{1}$, I. VASCONCELOS ${ }^{1}$, J. MEXIA ${ }^{2}$, A. LÉONARD ${ }^{3}$, \\ I. SANZHAR ${ }^{4}$, N. AKHMATULLINA ${ }^{4}$ and J. RUEFF ${ }^{1}$
}

\begin{abstract}
${ }^{1}$ Department of Genetics, Faculty of Medical Sciences, New University of Lisbon, R. da Junqueira 96, P-1349-008 Lisbon; ${ }^{2}$ Department of Mathematics, Faculty of Sciences and Technology, New University of Lisbon, Monte da Caparica, Portugal; ${ }^{3}$ Catholic University of Louvain, Faculty of Medicine, Brussels, Belgium; ${ }^{4}$ Institute of General Genetics and Cytogenetics, Academy of Science, Almaty, Kazakhstan
\end{abstract}

Received July 24, 2007; Accepted November 15, 2007

\begin{abstract}
The present study aimed to correlate the DNA replication timing of different genes with genetic damage and frequency of cancer. Using a fluorescence in situ hybridisation (FISH) approach, the replication timing of three loci, two human genes possessing transcriptional capability and involved in both the cellular response to genetic damage and cancer development (TP53 and RB1) and the non-coding locus D22S163, was evaluated. The data obtained show that normal human lymphocytes exposed in vitro to known DNAdamaging agents, e.g. $\mathrm{H}_{2} \mathrm{O}_{2}$, ionizing radiation and mitomycin $\mathrm{C}$, exhibit an asynchronous replication of the genes TP53 and RB1. In vivo studies were performed in three different populations from Kazakhstan. In two of these populations that are living in polluted areas and have higher cancer mortalities than people living in a control area, a DNA replication behaviour similar to that observed in human lymphocytes exposed in vitro to known genotoxic agents was detected. The results obtained further indicate that DNA damage hampers replication and FISH represents a fast and accurate method of assessing asynchronous replication by providing an important tool to evaluate DNA damage at a populational level.
\end{abstract}

\section{Introduction}

Kazakhstan suffers from substantial pollution problems with consequential environmental impact. Numerous environmental agents are a threat to human genetic health. In particular,

Correspondence to: Dr José Rueff, Department of Genetics, Faculty of Medical Sciences, New University of Lisbon, R. da Junqueira 96, P-1349-008 Lisbon, Portugal

E-mail: rueff.gene@fcm.unl.pt

Key words: DNA replication timing, genetic damage, fluorescence in situ hybridisation, TP53, RB1,D22S163 radiation and some chemicals may lead to genetic changes in human cells that are considered an etiologic factor of cancer. Although the mortality rate for cancer has fallen in recent years in that country, it is one of the highest compared to other Central Asian countries and Europe (1). Two of the major objectives in population cancer risk evaluation are the increase of the accuracy of exposure assessment to potential environment carcinogens and the prediction of cancer outcome in exposed populations (2).

With respect to cytogenetic methods, the detection of unstable chromosome aberrations is the method of choice for most suspected cases of accidental overexposure when the analysis can be performed within months after exposure, but is unsuitable when a period of years has elapsed after the exposure because of the limited lifespan of unstable aberrations. The stable chromosome aberrations are observed after conventional banding alone or in combination with FISH methods, but these techniques are laborious and timeconsuming (3).

The development of simple, rapid and reliable assays is thus desirable in order to estimate the genetic damage and predict its consequences in human populations.

Replication timing studies have been used to monitor early and late replication, showing an altered replication phenotype in human cells with chromosomal aberrations $(4,5)$. These authors show that certain chromosomes carrying translocations display significant delayed replication timing, while a derivative human chromosome containing a homogeneously staining region (HSR) is primarily early replicating. Early replication timing has also been reported in association with the expression of both the RET gene (6) and the translocated $B C L-2$ gene (7).

Recent evidence has suggested a number of interrelationships between DNA replication and cellular DNA damage responses (reviewed in ref. 8). In fact, Merrick et al (9) observed altered replication dynamics after DNA damage in human cells, showing that exposing S-phase cells to ionizing radiation induces a transient block to origin firing but does not affect the fork rate or fork stalling. 
Fluorescence in situ hybridisation (FISH) analysis could be used on interphase nuclei to determine the replication timing of DNA (10-12). This assay has many parallels with the assay developed by Woodfine et al (13) using genomic clone DNA microarrays to assess the replication timing of sequences during the $\mathrm{S}$ phase of the cell cycle. However, the FISH analysis presents an advantage on the detection of the DNA replication asynchrony which could not be detected by the approach described by Woodfine et al (13) since the ratio reported by these authors is a combination of the replication timing of the two alleles. Using FISH methodology it was shown that lymphocytes derived from patients with haematological malignancies (14), renal carcinoma (15) and neurofibromatous type 1 (16) display a loss of synchrony in allelic replication timing.

The present study was primarily aimed at assessing replication asynchrony in populations with a high mortality rate of cancer due to their living in polluted areas.

Two human genes possessing transcriptional capability and involved in both the cellular response to genetic damage and cancer development (TP53 and RB1) and the non-coding locus D22S163 were studied by a FISH-based approach to determine the timing of replication. Replicated loci are visualized as double-dot hybridisation signals (biallelic replicated state), whereas the unreplicated loci are visible as single dots. Genes undergoing non-synchronous DNA replication appear as one singlet and one doublet in the interphase nuclei (monoallelic timing of replication). Thus, the allelic counterparts replicating asynchronously give rise to a high frequency of cells with one singlet and one doublet (SD cells). By scoring at least 200 cells one can assess whether a gene is early, late or asynchronously replicating.

In order to optimise the FISH method for further application to the populations described below and calibrate the frequency of cells with asynchronous replication of the TP53 and RBI genes, cells from healthy non-smoker volunteers, who were not exposed to radiation or drugs, were treated in vitro with ionising radiation, mitomycin $\mathrm{C}$ or hydrogen peroxide. A FISH analysis and the parallel scoring of chromosome aberrations in metaphase spreads were carried out in the same aliquots of cells.

The replication timing of the three loci was investigated in populations living in two polluted areas of Kazakhstan, Ust-Kamenogorsk and Aktau (Mangistau area, Kora lake). Volunteers from the Almaty area (Chylik) served as controls. Populations living in the Ust-Kamenogorsk area have a high mortality rate from cancer of various organs (Table I) whereas populations from Aktau have a high mortality rate of oesophagus and colon cancer and leukaemia as compared in both cases with the control region of Almaty.

\section{Materials and methods}

Subjects. For in vitro exposure to genotoxic agents, blood was withdrawn by venipuncture from 7 healthy Portuguese volunteers who were non-smokers and without recent exposure to drugs or radiation.

In vivo studies were performed in three populations from the Kazakhstan areas of: i) Ust-Kamenogorsk, ii) Aktau (Mangistau area, Kora lake) and iii) Almaty (Chylik). The
Table I. Tumour sites for which there is an increased mortality rate in Ust-Kamenogorsk as compared to the Almaty area (per 100,000 inhabitants, in the year 2000).

\begin{tabular}{lcc}
\hline Organs & $\begin{array}{c}\text { Ust-Kamenogorsk } \\
\text { area }\end{array}$ & $\begin{array}{c}\text { Control group } \\
\text { (Almaty area) }\end{array}$ \\
\hline Mouth and throat & 4.1 & 2.4 \\
Stomach & 34.0 & 14.3 \\
Colon & 13.0 & 2.8 \\
Rectum & 11.4 & 3.6 \\
Lung & 44.2 & 16.4 \\
Bones & 4.7 & 2.3 \\
Skin & 2.2 & 0.8 \\
Breast & 14.3 & 7.2 \\
Ovary & 5.4 & 2.7 \\
Prostate & 3.8 & 1.7 \\
Urinary bladder & 4.7 & 1.7 \\
Lymphoma & 5.0 & 1.7 \\
Leukemia & 5.0 & 2.2 \\
\hline
\end{tabular}

first two populations are living in polluted areas and have a high mortality from cancer and the third is a control population. The data on cancer mortality was obtained from the Laboratory of Scientific Management in the Fight Against Cancer and Application of the Kazakh Scientific Research Institute of Oncology and Radiology, Ministry of Health of the Republic of Kazakhstan. The tumour sites for which there is an increased mortality in the Ust-Kamenogorsk area compared with the control area is indicated in Table I. In the Aktau (Mangistau area, Kora lake) region the total mortality rate from cancer in 2000 was similar to the Almaty control area (96.9 vs. 100.6 per 100 000). However, the oesophagus and colon cancer and leukaemia had higher mortality rates in Aktau, respectively, 15.6 vs. 7.7, 4.1 vs. 2.8 and 4.4 vs. 2.2.

Cell suspensions in fixative were received from 24 inhabitants from the Ust-Kamenogorsk area, 25 inhabitants from Aktau (Mangistau area, Kora lake) and 20 inhabitants from the Almaty area (Chylik).

In vitro exposure to genotoxic agents. For irradiation, the blood was exposed to X-rays (1 and 2 Gy) using a Varian linear accelerator model Clinac 2100 (C/D). Non-irradiated blood was treated with mitomycin $\mathrm{C}(0.3$ and $1.5 \mu \mathrm{M})$ or $\mathrm{H}_{2} \mathrm{O}_{2}$ $(15$ and $20 \mathrm{mM})$ at $24 \mathrm{~h}$ of culture. These doses were chosen since they produce a significant induction of genetic damage (17).

Cell cultures. Aliquots of $0.5 \mathrm{ml}$ of heparinized whole blood were cultured in $4.5 \mathrm{ml}$ Ham's F10 medium supplemented with $24 \%$ foetal calf serum, penicillin $(100 \mathrm{IU} / \mathrm{ml})$, streptomycin $(100 \mu \mathrm{g} / \mathrm{ml}), 1 \%$ L-glutamine and $1 \%$ heparin (50 IU/ml). Lymphocytes were stimulated using $25 \mu \mathrm{l}$ of phytohemagglutinin (PHA) and incubated at $37^{\circ} \mathrm{C}$ for $48 \mathrm{~h}$. Two hours before harvesting the cells, $0.1 \mathrm{ml}$ of a $4 \mathrm{mg} / 100 \mathrm{ml}$ solution of colchicine was added. Cells were harvested by 
centrifugation, submitted to hypotonic treatment and fixed with cold methanol : acetic acid (3:1). Cells were spread on slides and stained with Giemsa or stored at $-20^{\circ} \mathrm{C}$ for further use in FISH analysis. Preparations for FISH were made by applying one or two drops of cell suspension on silanized slides.

Probes. For hybridisation, labelled commercial probes obtained from Vysis, Inc. were used for the three loci studied: the TP53 probe (32-190004), RB1 probe (32-190001) and MS607 probe (33-260022), a minisatellite probe from locus D22S163. The probe mixtures were prepared according to the manufacturer's instructions.

In situ hybridisation. Preparations were dehydrated in $100 \%$ EtOH for $5 \mathrm{~min}$, denaturated for $1.5 \mathrm{~min}$ in $70 \%$ formamide/ 2X SSC ( $\mathrm{pH} \mathrm{7.5)} \mathrm{at} 73^{\circ} \mathrm{C}$ and dehydrated again in a graded ethanol series. Probe hybridisation was performed for $20 \mathrm{~h}$ at $37^{\circ} \mathrm{C}$ in a moist chamber. Slides were then washed following the manufacturer's protocol and counterstained with DAPI (Vysis).

Cytogenetic evaluation. Slides were analysed on a Nikon Optiphot microscope coupled to a CytoVision system from Applied Imaging. Cy3 and DAPI filters were used. The DNA replication timing evaluation was done whenever possible in 200 nuclei for each individual and each probe. The same was done in the in vitro study for each dose of each genotoxic agent. Scoring was only done when the following criteria were met: i) nuclei had intact morphology, ii) nuclei did not overlap and iii) both hybridisation signals were visible. As illustrated in Fig. 1, non-replicated sequences were detected as two single hybridisation signals (SS) and sequences that have a completed replication were detected as two double hybridisation signals (DD). Sequences undergoing nonsynchronous DNA replication appeared as one singlet and one doublet (SD).

To test for hybridisation efficiency, metaphase spreads were examined for the number of hybridisation signals at each chromosome copy. The level of SDs attributed to incomplete hybridisation was $10 \%$ at maximum, consistent with previous reports (18).

The scoring of chromosomal aberrations was assessed according to the criteria described by Rueff et al (17).

Statistical analysis. In order to analyse the data in vivo the one-way ANOVA was used to check if differences between the cities in the study existed. The Scheffé method was used in the cases where differences were found to exist, to select the pairs of cities, which differed significantly at the $5 \%$ level. The statistical analysis of the homogeneity of age $(<30$, 30-39, 40-49 and $\geq 50$ years), gender and smoking habits (smokers and non-smokers) and distributions between exposed and control populations was carried out using the $\chi^{2}$ test.

For the data in vitro, two-way ANOVA was used to check the existence of differences between the treatments. The Scheffé method was again used. The Dunnett method was used in order to detect if the treatments were significantly higher or lower than the controls. The correlations of different variables were determined by the Pearson correlation test. The

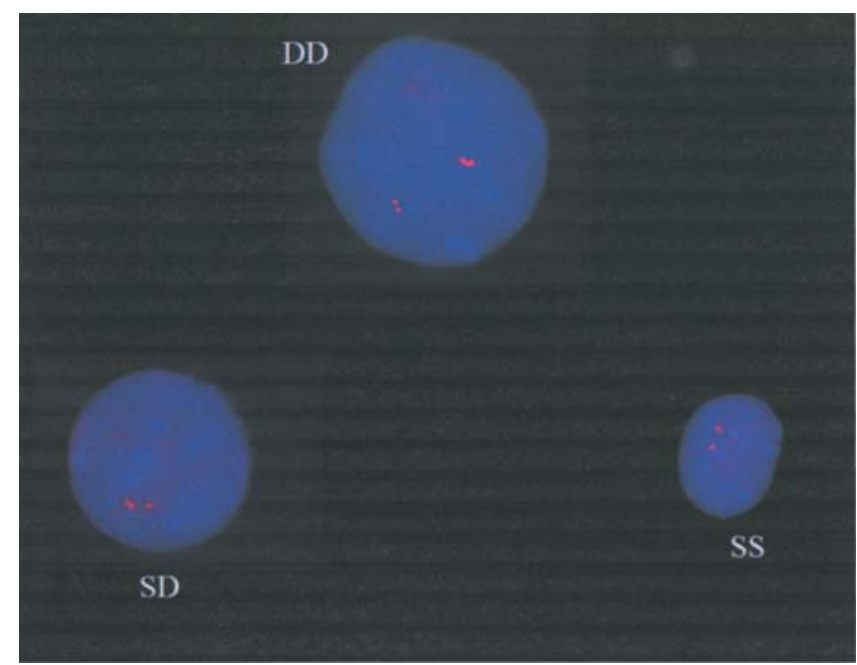

Figure 1. Hybridization signals of replication, using three different DNA probes: TP53, RB1 and MS607. (DD) A nucleus exhibiting two double hybridization signals (DD), obtained with a TP53 probe. (SD) A nucleius exhibiting one single and one double hybridization signal (SD), obtained with an $R B 1$ probe. (SS) A nucleus exhibiting two single hybridization signals (SS), obtained with an MS607 probe.

differences were considered significant at the 5\% level for all the analyses performed.

\section{Results}

DNA replication timing in normal human lymphocytes exposed to genotoxic agents (in vitro study). The frequency of the SS cells for TP53 and RB1 in peripheral blood lymphocytes prior to exposure to the genotoxic agents was $81 \pm 6$ and $84 \pm 8 \%$ (mean and standard deviation). The frequencies of the SD and DD cells were low, 13 \pm 4 and $7 \pm 2 \%$ for $T P 53$ and $9 \pm 5$ and $7 \pm 5 \%$ for $R B 1$, indicating the synchronous replication of the TP53 and RBI genes. However, after cell culture exposure to X-rays ( $2 \mathrm{~Gy}$ ) the corresponding values of the SS cells decreased to $65 \pm 4$ and $61 \pm 5 \%$ for $T P 53$ and $R B 1$, respectively (Figs. 2 and 4). For both the TP53 and RBI genes, the decrease of the SS cells and the increase of the SD cells caused by the X-rays ( $2 \mathrm{~Gy}$ ) were statistically significant $(\mathrm{P}<0.05)$, indicating that one of the alleles of each locus replicated earlier than the other allele (Figs. 2 and 4). After the exposure to a lower dose of ionising radiation (1 Gy) a statistically significant increase of SD and DD cells was observed when the $R B 1$ probe was used $(\mathrm{P}<0.05$, Fig. 4). Comparing these effects with the induction of chromosomal aberrations, we could detect a significant Pearson correlation between dicentrics formation and the frequency of SD cells when the $R B 1$ probe was used ( $\mathrm{r}=0.999$, $\mathrm{p}=0.026$ ). A similar correlation was observed when the TP53 probe was used but this did not reach the significant level.

Mitomycin $\mathrm{C}(0.3$ and $1.5 \mu \mathrm{M})$ also led to an asynchronous replication evidenced by the significant decrease of the SS cells and the significant increase of the SD cells after treatments $(\mathrm{P}<0.05)$. Using the TP53 probe, the frequency of the SS cells was $59 \pm 11$ and $66 \pm 10 \%$ and the frequency of the SD cells was $25 \pm 8$ and $26 \pm 12 \%$ after exposure to 0.3 and 


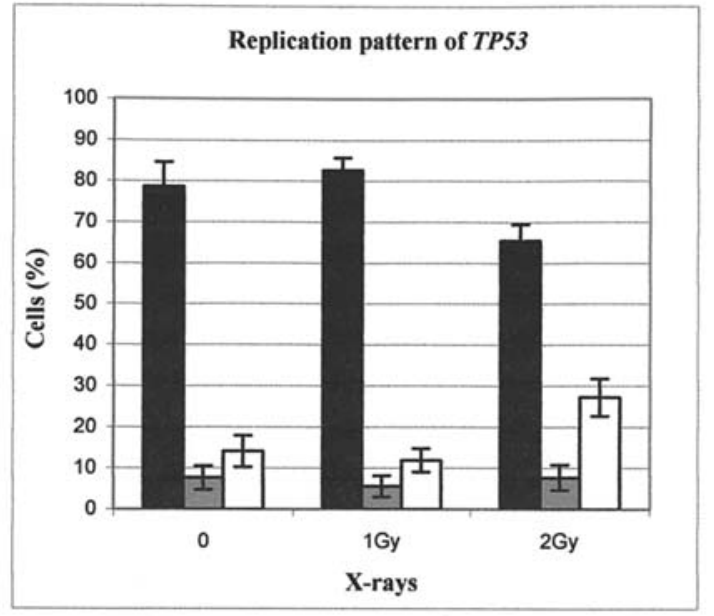

Figure 2. Replication pattern of the TP53 locus in cells exposed to ionizing radiation (1 and $2 \mathrm{~Gy})$. Each bar represents the mean of percentages of the SS, DD and SD nuclei. Black, SS; grey, DD; white, SD. Error bars represent standard deviation. The statistical analysis indicates a significant decrease of the SS cells and a significant increase of the SD cells after exposure to Xrays ( $2 \mathrm{~Gy})$.

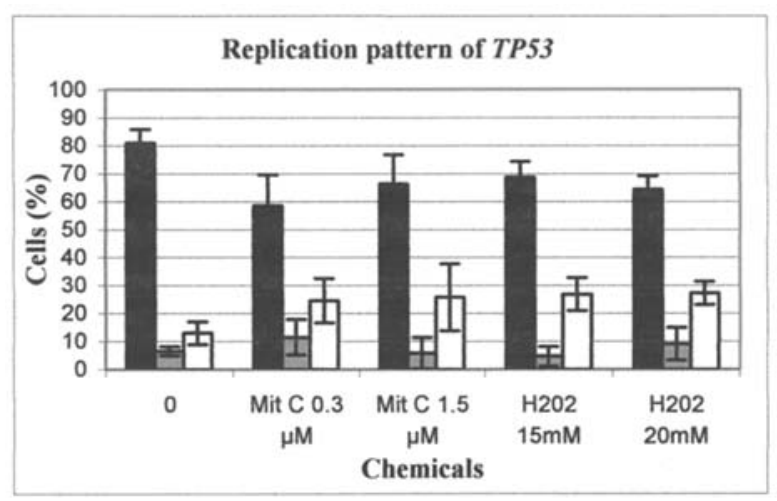

Figure 3. Replication pattern of the TP53 locus in cells exposed to the chemicals mitomycin $\mathrm{C}(0.3$ and $1.5 \mu \mathrm{M})$ and $\mathrm{H}_{2} \mathrm{O}_{2}(15$ and $20 \mathrm{mM})$. Each bar represents the mean of percentages of the SS, DD and SD nuclei. Black, SS; grey, DD; white, SD. Error bars represent standard deviation. The statistical analysis indicates a significant decrease of the SS cells and a significant increase of the SD cells after exposure to chemicals.

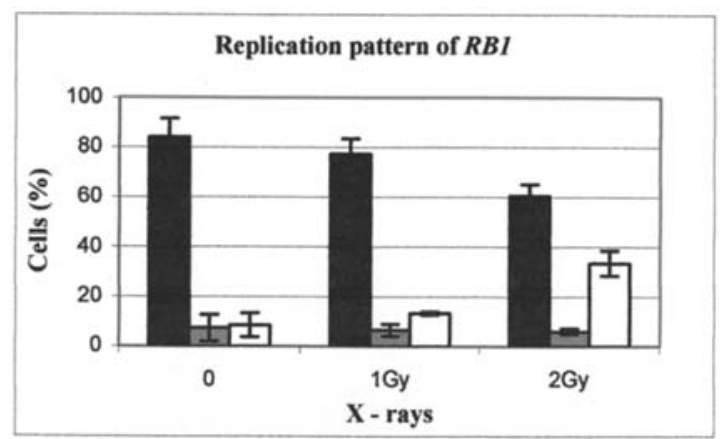

Figure 4. Replication pattern of the $R B 1$ locus in cells exposed to ionizing radiation ( 1 and $2 \mathrm{~Gy})$. Each bar represents the mean of percentages of the SS, DD and SD nuclei. Black, SS; grey, DD; white, SD. Error bars represent standard deviation. The statistical analysis indicates a significant decrease of the SS cells and a significant increase of the SD cells after exposure to $\mathrm{X}$ rays (1 and $2 \mathrm{~Gy}$ ).

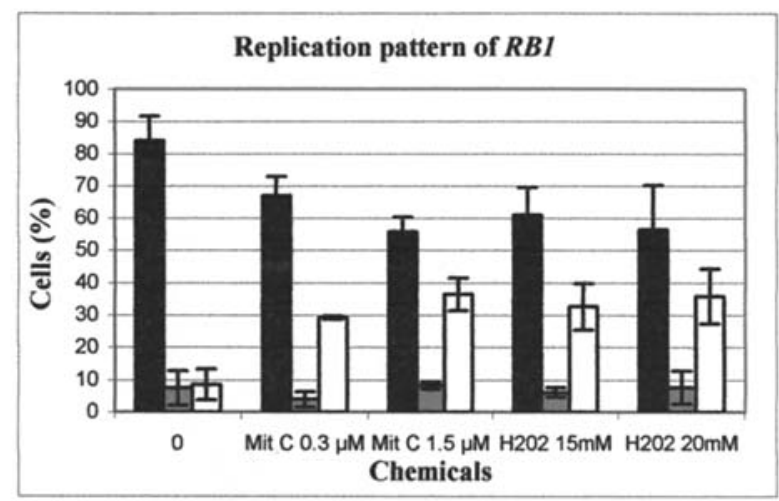

Figure 5. Replication pattern of the RB1 locus in cells exposed to the chemicals mitomycin $\mathrm{C}(0.3$ and $1.5 \mu \mathrm{M})$ and $\mathrm{H}_{2} \mathrm{O}_{2}(15$ and $20 \mathrm{mM})$. Each bar represents the mean of percentages of the SS, DD and SD nuclei. black, SS; grey, DD; white, SD. Error bars represent standard deviation. The statistical analysis indicates a significant decrease of the SS cells and a significant increase of the SD cells after exposure to chemicals.

$1.5 \mu \mathrm{M}$, respectively (Fig. 3). Using the $R B 1$ probe, the frequency of the SS cells was $67 \pm 8$ and $56 \pm 14 \%$ and the frequency of the SD cells was $29 \pm 7$ and $36 \pm 9 \%$ after exposure to 0.3 and $1.5 \mu \mathrm{M}$, respectively (Fig. 5).

$\mathrm{H}_{2} \mathrm{O}_{2}$ (15 and $20 \mathrm{mM}$ ) also led to an asynchrony of replication for both the TP53 and $R B 1$ genes. Using the TP53 probe, the frequency of the SS cells was $69 \pm 6$ and $64 \pm 5 \%$ and the frequency of the SD cells was $27 \pm 6$ and $27 \pm 4 \%$ after exposure to 15 and $20 \mathrm{mM}$, respectively (Fig. 3). Using the $R B 1$ probe, the frequency of the SS cells was $61 \pm 8$ and $57 \pm 11 \%$ and the frequency of the SD cells was $33 \pm 7$ and $36 \pm 9 \%$ after exposure to 15 and $20 \mathrm{mM}$, respectively (Fig. 5). The statistical analysis revealed a significant decrease of the SS cells and a significant increase of the SD cells in the treated cells $(\mathrm{P}<0.05)$.

Globally, all the genotoxic agents used in the in vitro study, $\mathrm{X}$-rays, $\mathrm{H}_{2} \mathrm{O}_{2}$ and mitomycin $\mathrm{C}$ produced a significant decrease of the SS nuclei and a significant increase of the SD nuclei when the two probes TP53 and RBI were used (Table II and Figs. 2, 3, 4 and 5). Thus, genotoxic agents led to an asynchronous replication of DNA.

DNA replication timing in populations from Kazakhstan (in vivo study). The DNA replication timing assay by FISH was applied to the very same conditions to study human populations living in areas with different levels of pollution and displaying a high mortality rate from malignant tumours. While the population from Aktau (Mangistau area, Kora lake) had a high mortality from oesophagus and colon cancer and leukaemia, the population from the Ust-Kamenogorsk area had a high mortality from malignant tumours of several different organs (Table I). The study groups from Almaty, Aktau and Ust-Kamenogorsk were matched for age group, gender and smoking habits, with no significant differences $\left(\chi^{2}\right.$ test).

The frequency of the SS cells for TP53 and RBI in peripheral blood lymphocytes in the control population (Almaty area) was $82 \pm 7$ and $79 \pm 7 \%$, respectively. For TP53, the frequency of the SD cells and DD cells was $10 \pm 4$ and 
Table II. Replication pattern of the TP53 and RBI loci in human lymphocytes exposed in vitro to ionizing radiation (1 and 2 Gy), chemicals (mitomycin $\mathrm{C}$ and $\mathrm{H}_{2} \mathrm{O}_{2}$ ) and controls.

\begin{tabular}{lcccccr}
\hline Dose & \multicolumn{3}{c}{ TP53 } & \multicolumn{2}{c}{$R B 1$} \\
\cline { 2 - 6 } & SS $(\%)$ & DD $(\%)$ & SD $(\%)$ & SS $(\%)$ & DD $(\%)$ & SD $(\%)$ \\
\hline 0 & $81 \pm 6$ & $7 \pm 2$ & $13 \pm 4$ & $84 \pm 8$ & $7 \pm 5$ & $9 \pm 5$ \\
$1 \mathrm{~Gy}$ & $83 \pm 3$ & $6 \pm 3$ & $12 \pm 3$ & $77 \pm 6$ & $7 \pm 2$ & $13 \pm 1$ \\
$2 \mathrm{~Gy}$ & $65 \pm 4$ & $8 \pm 3$ & $27 \pm 5$ & $61 \pm 5$ & $6 \pm 1$ & $34 \pm 5$ \\
Mit. C $0.3 \mu \mathrm{M}$ & $59 \pm 11$ & $12 \pm 6$ & $25 \pm 8$ & $67 \pm 8$ & $4 \pm 1$ & $29 \pm 7$ \\
Mit. C $1.5 \mu \mathrm{M}$ & $66 \pm 10$ & $6 \pm 6$ & $26 \pm 12$ & $56 \pm 14$ & $8 \pm 5$ & $36 \pm 9$ \\
$\mathrm{H}_{2} \mathrm{O}_{2} 15 \mathrm{mM}$ & $69 \pm 6$ & $5 \pm 4$ & $27 \pm 6$ & $61 \pm 8$ & $6 \pm 3$ & $33 \pm 7$ \\
$\mathrm{H}_{2} \mathrm{O}_{2} 20 \mathrm{mM}$ & $64 \pm 5$ & $9 \pm 6$ & $27 \pm 4$ & $57 \pm 11$ & $8 \pm 3$ & $36 \pm 9$ \\
\hline
\end{tabular}

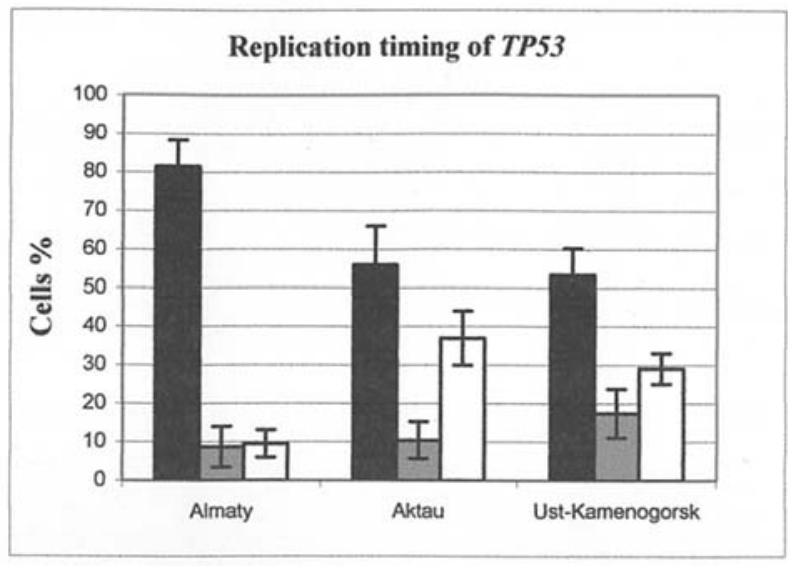

Figure 6. Replication timing of the TP53 locus in the Kazakhstan populations, living in the Almaty (Chylik), Ust-Kamenogorsk and Aktau (Mangistau area, Kora Lake) areas. Each bar represents the mean of percentages of the SS, DD and SD nuclei. Black, SS; grey, DD; white, SD. Error bars represent standard deviation. The statistical analysis indicates a significant decrease of the SS cells and a significant increase of the SD cells, in the individuals living in the Ust-Kamenogorsk and Aktau areas (Mangistau area, Kora Lake) when compared with the controls from Almaty.

$9 \pm 5 \%$, respectively. For $R B 1$, the frequency of SD and DD cells was $12 \pm 3$ and $9 \pm 4$. These data indicate a synchrony of replication in the control population.

In contrast, in individuals from Aktau (Mangistau area, Kora lake) and the Ust-Kamenogorsk areas a decreased number of SS cells and a higher number of SD cells were detected when the replication timing of both the TP53 and RBI genes were studied as compared to the controls from Almaty $(\mathrm{P}<0.001$, Table III and Figs. 6 and 7). The SS frequencies decreased to $56 \pm 10$ and $61 \pm 11 \%$ in the Aktau area and $53 \pm 7$ and $59 \pm 7 \%$ in the Ust-Kamenogorsk area. The SD frequencies increased to $37 \pm 7$ and $30 \pm 8 \%$ in Aktau and $29 \pm 4$ and $30 \pm 5 \%$ in the Ust-Kamenogorsk area. The frequency of DD cells in Ust-Kamenogorsk also increased as compared with the control area $(17 \pm 6$ vs. $9 \pm 5 \%)$ for the TP53 gene (P<0.001, Fig. 6).

Taken together these results suggest that individuals living in polluted areas have a higher DNA replication asynchrony when compared with the control population living in Almaty. Additionally, when the population of Ust-Kamenogorsk, a

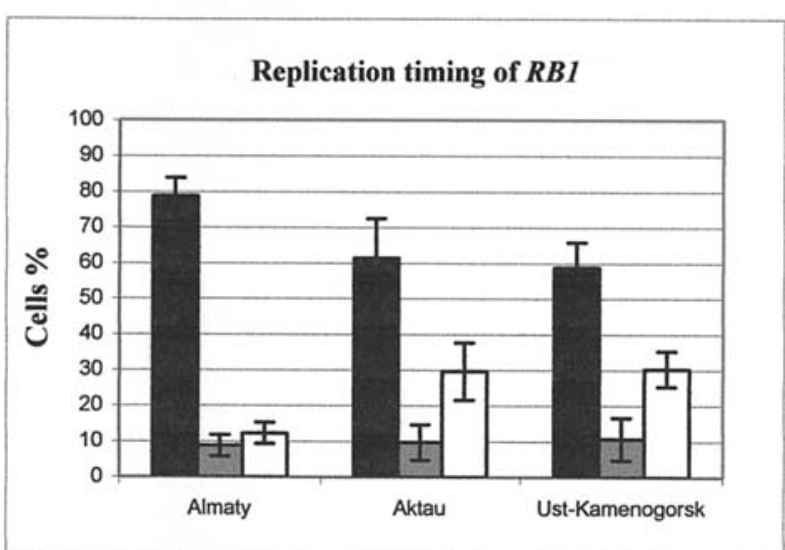

Figure 7. Replication timing of the RB1 locus in the Kazakhstan populations, living in the Almaty (Chylik), Ust-Kamenogorsk and Aktau (Mangistau area, Kora Lake) areas. Each bar represents the mean of percentages of the SS, DD and SD nuclei. Black, SS; grey, DD; white, SD. Error bars represent standard deviation. The statistical analysis indicates a significant decrease of the SS cells and a significant increase of the SD cells, in the individuals living in the Ust-Kamenogorsk and Aktau areas (Mangistau area, Kora Lake) when compared with the controls from Almaty.

polluted area with a higher cancer mortality rate than Aktau, was compared with this one, a statistically significant difference in DNA replication patterns for TP53 and D22S163 loci was observed $(\mathrm{P}<0.005$, Table III).

Although a difference in the SS and SD patterns was noted between the Almaty and Aktau populations when the D22S163 locus was studied $(\mathrm{P}<0.001)$, we could not detect any statistically significant difference between Almaty and Ust-Kamenogorsk using the same probe (Table III).

Additionally, when the replication timing of the three loci was compared, the $D 22 S 163$ locus significantly differed from both the TP53 and RB1 genes $(\mathrm{P}<0.002)$.

\section{Discussion}

A wide range of environmental genotoxic agents can react with DNA or stimulate the production of reactive oxygen species, leading to DNA damage. DNA lesions may alter the conformational properties of strands at the replication fork, 
Table III. Replication pattern of TP53, RB1 and D22S163 loci in lymphocytes from the Kazakhstan populations, living in the Almaty (Chylik), Ust-Kamenogorsk and Aktau areas (Mangistau area, Kora Lake).

\begin{tabular}{|c|c|c|c|c|}
\hline Area & Locus & SS (\%) & $\mathrm{DD}(\%)$ & $\mathrm{SD}(\%)$ \\
\hline \multirow[t]{3}{*}{ Almaty (Control) } & TP53 & $82 \pm 7$ & $9 \pm 5$ & $10 \pm 4$ \\
\hline & $R B 1$ & $79 \pm 7$ & $9 \pm 4$ & $12 \pm 3$ \\
\hline & $D 22 S 163$ & $91 \pm 5$ & $4 \pm 3$ & $5 \pm 3$ \\
\hline \multicolumn{5}{|l|}{ Aktau } \\
\hline & TP53 & $56 \pm 10$ & $7 \pm 5$ & $37 \pm 7$ \\
\hline & $R B 1$ & $61 \pm 11$ & $10 \pm 5$ & $30 \pm 8$ \\
\hline & $D 22 S 163$ & $82 \pm 3$ & $7 \pm 3$ & $11 \pm 3$ \\
\hline \multicolumn{5}{|l|}{ Ust-Kamenogorsk } \\
\hline & TP53 & $53 \pm 7$ & $17 \pm 6$ & $29 \pm 4$ \\
\hline & $R B 1$ & $59 \pm 7$ & $11 \pm 6$ & $30 \pm 5$ \\
\hline & D22S163 & $92 \pm 8$ & $2 \pm 3$ & $5 \pm 5$ \\
\hline
\end{tabular}

thus affecting the selectivity of polymerases and the fidelity of transcriptional machinery (19). DNA lesions are also triggering events of chromosomal aberrations. Chromosome translocations result in the generation of delays in replication timing/delay in the mitotic chromosome condensation phenotype. This phenotype occurs frequently in tumour cells and in cells exposed to ionising radiation both in vitro and in vivo $(4,5)$. Other chromosome alterations such as HSRs are early replicating (4).

A switch to early replication precedes or coincides with the transcriptional activation of genes within the affected domain (20). Using genomic clone DNA microarrays to assess the replication timing of sequences in human genome during the $\mathrm{S}$ phase of the cell cycle, Woodfine et al (13) show a positive correlation between replication timing and transcriptional activity. Moreover, the DNA replication-timing analysis of the human chromosome 22 revealed that expressed sequences are replicated earlier than non-transcribed regions (21).

The data obtained in the present study, show that known DNA-damaging agents, e.g. $\mathrm{H}_{2} \mathrm{O}_{2}$, ionising radiation and mitomycin $\mathrm{C}$ led to an asynchronous replication timing of the genes TP53 and RB1. This is demonstrated by the significant decrease of the SS cells and the significant increase of the SD cells (Table II and Figs. 2, 3, 4 and 5).

These data may be explained by the exposure to genotoxic agents which leads to a large spectrum of DNA and chromosomal lesions, some of which give rise to aberrations in the replication timing in the site of the lesions. The positive correlation between dicentrics formation, the specific lesion of radiation and the frequency of SD cells found, suggests that DNA and chromosomal damage may be associated with asynchronous DNA replication.

Moreover, agents that introduce lesions in DNA could transiently inhibit DNA synthesis. This inhibition results in an altered replication control documented by the increased number of initiations of DNA synthesis (reviewed in ref. 22).

An asynchronous replication of the TP53 and RBI genes in association with their activation cannot be ruled out. Both p53 and RB are two main tumour-suppressor pathways that control cellular responses to potentially oncogenic stimuli (reviewed in ref. 23). It was reported that p53 is usually moderately expressed in normal cells and becomes active under stressful conditions (24) and can be activated by a wide spectrum of DNA-damaging agents. Its induction is an indicator of genotoxic damage (25). Islaih et al (26) exposed the human TK6 lymphoblastoid cell line to genotoxicants that cause genotoxic stress by many different mechanisms, including covalent modification and reactive oxygen species and found an activation of the p53 pathway in all the compounds. Comparing gene-expression profiles measured in human cells stably knocked down for ATM, NF- $\mathrm{BB}$ and p53, Elkon et al observed that NF-кB and p53 mediated most of the damage-induced gene activation (27).

One of the major roles of p53 in stress response is that of a sequence-specific transcription factor and $R B 1$ is a p53 effector (28).

The populations from the Ust-Kamenogorsk area and Aktau (Mangistau area, Kora lake) are seemingly exposed to genotoxic agents as a consequence of pollutant exposure. The former has an important mortality from malignant tumours of different organs and the latter has a high mortality from oesophagus and colon cancer and leukaemia as compared with the control region Almaty (Table I).

In individuals from these two areas an increase of the SD cells and a decrease of the SS cells was detected for the TP53 and $R B 1$ genes as compared to the controls (Table III and Figs. 6 and 7). This behaviour is similar to that observed in human lymphocytes exposed in vitro to known genotoxic agents. In individuals from the Ust-Kamenogorsk area the percentage of cells where the two TP53 alleles are both replicated (DD cells) is significantly higher than in the controls from Almaty, indicating a switch to early $\mathrm{S}$ phase.

On the other hand, given the significant difference in the SS and SD patterns noted between the Almaty and Aktau populations as well as in the SS, SD and DD patterns between Aktau and Ust-Kamenogorsk, when the D22S163 locus was studied, we could not rule out that these abnormalities in the DNA replication timing may contribute to put into evidence 
an overall, non-locus-specific event associated with genetic instability. This event seems not to exclude the association between DNA lesions, activity of TP53 and RBI and replication asynchrony, because the replication pattern of the D22 S163 locus significantly differs from those of the TP53 and $R B 1$ loci.

Although asynchronous replication is characteristic of monoallelic expression in imprinted genes and is therefore an epigenetic mark (29), the data presented seem to indicate that DNA lesions may result in the asynchrony of DNA replication.

Taken together the present data suggest that asynchronous DNA replication as detected by FISH may be a potentially useful and predictive approach in estimating exposure to genotoxic/carcinogenic agents. The application of this methodology in larger populations could give rise to an important tool for the identification of highly-exposed individuals at the population level, allowing for public health strategies in order to reduce cancer mortality.

\section{Acknowledgements}

The authors thank Dr Sá da Costa for his contribution to our work with the irradiation of human lymphocytes, as well as Dr E. Moreira and Dr S. Oliveira for their invaluable help in the statistical analysis. We are also indebted to Dr J. Gaspar and Dr A. Rodrigues for their helpful suggestions and for a critical reading of the manuscript. This work has been performed in the framework of the contract number ICA 2CT-2000-10056 (EU). Our current research is also supported by the Luso-American Foundation for Development and 'Liga Portuguesa contra o Cancro').

\section{References}

1. UNECE - United Nations Economic Commission for Europe. Economic and Social Council. Committee on Environment Policy. Environmental Performance review of Kazakhstan (http://www. unece.org/env/epr/studies/kazakhstan).

2. $\mathrm{Au} \mathrm{W}$ : Usefulness of biomarkers in population studies: from exposure to susceptibility and prediction of cancer. Int $\mathrm{J} \mathrm{Hyg}$ Environ Health 210: 239-246, 2007.

3. Léonard A, Rueff J, Gerber GB and Leonard ED: Usefulness and limits of biological dosimetry based on cytogenetic methods. Radiat Prot Dosimetry 115: 448-454, 2005.

4. Smith L, Plug A and Thayer M: Delayed replication timing leads to delayed mitotic chromosome condensation and chromosomal instability of chromosome translocations. Proc Natl Acad Sci USA 98: 13300-13305, 2001.

5. Breger KS, Smith L, Turker MS and Thayer MJ: Ionizing radiation induces frequent translocations with delayed replication and condensation. Cancer Res 64: 8231-8238, 2004.

6. Cinti R, Schema F, Passalacqua M, Ceccherini I and Ravazzolo R: Replication pattern of the pericentromeric region of chromosome $10 \mathrm{q}$ and expression of the RET protooncogene. Exp Cell Res 298: 602-610, 2004.

7. Sun Y, Wyatt RT, Bigley A and Krontiris TG: Expression and replication timing patterns of wild-type and translocated BCL2 genes. Genomics 73: 161-170, 2001.

8. Andreassen PR, Ho G and D' Andrea AD: DNA damage responses and their many interactions with the replication fork. Carcinogenesis 27: 883-892, 2006.

9. Merrick CJ, Jackson D and Diffley JFX: Visualization of altered replication dynamics after DNA damage in human cells. J Biol Chem 279: 20067-20075, 2004.
10. Selig S, Okumura K, Ward DC and Cedar H: Delineation of DNA replication time zones by fluorescence in situ hybridization. EMBO J 11: 1217-1225, 1992.

11. Boggs BA and Chinault AC: Analysis of DNA replication by fluorescence in situ hybridization. Methods 13: 259-270, 1997.

12. Goren A and Cedar H: Replicating by the clock. Nat Rev Mol Cell Biol 4: 25-32, 2003.

13. Woodfine K, Fiegler H, Beare DM, Collins J, McCann O, Young B, Debernardi S, Mott R, Dunham I and Carter N: Replication timing of the human genome. Hum Mol Genet 13: 191-202, 2004.

14. Amiel A, Elis A, Sherker S, Gaber E, Manor Y and Fejgin MD: The influence of cytogenetic aberrations on gene replication in chronic lymphocytic leukemia patients. Cancer Genet Cytogenet 125: 81-86, 2001 .

15. Dotan ZA, Dotan A, Litmanovitch T, Ravia Y, Oniashvili N, Leibovitch I, Ramon J and Avivi L: Modification in the inherent mode of allelic replication in lymphocytes of patients suffering from renal cell carcinoma: a novel genetic alteration associated with malignancy. Genes Chromosomes Cancer 27: 270-277, 2000.

16. Reish O, Orlovski A, Mashevitz M, Sher C, Libman V, Rosenblat $M$ and Avivi L: Modified allelic replication in lymphocytes of patients with neurofibromatosis type 1. Cancer Genet Cytogenet 143: 133-139, 2003.

17. Rueff J, Bras A, Cristovao L, Mexia J, Sa da Costa M and Pires V: DNA strand breaks and chromosomal aberrations induced by $\mathrm{H}_{2} \mathrm{O}_{2}$ and ${ }^{60} \mathrm{Co}$ gamma-radiation. Mutat Res 289: 197-204, 1993.

18. Ofir R, Wong ACC, McDermid HE, Skorecki KL and Selig S: Position effect of human telomeric repeats on replication timing. Proc Natl Acad Sci USA 96: 11434-11439, 1999.

19. Malins DC, Polissar NL, Ostrander GK and Vinson MA: Single 8-oxo-guanine and 8-oxo-adenine lesions induce marked changes in the backbone structure of a 25-base DNA strand. Proc Natl Acad Sci USA 97: 12442-12445, 2000.

20. Gilbert DM: Replication timing and transcriptional control: beyond cause and effect. Curr Opin Cell Biol 14: 377-383, 2002 .

21. White EJ, Emanuelsson O, Scalzo D, Royce T, Kosak S, Oakeley EJ, Weissman S, Gerstein M, Groudine M, Snyder M and Schubeler D: DNA replication-timing analysis of human chromosome 22 at high resolution and different developmental states. Proc Natl Acad Sci USA 101: 17771-17776, 2004.

22. Schimke RT, Sherwood SW, Hill AB and Johnston RN: Overreplication and recombination of DNA in higher eukaryotes: potential consequences and biological implications. Proc Natl Acad Sci USA 83: 2157-2161, 1986.

23. Campisi J: Cancer and aging: rival demons? Nat Rev Cancer 3: 339-349, 2003.

24. Levine AJ: p53, the cellular gatekeeper for growth and division. Cell 88: 323-331, 1997.

25. Yang J and Duerksen-Hughes P: A new approach to identifying genotoxic carcinogens: p53 induction as an indicator of genotoxic damage. Carcinogenesis 19: 1117-1125, 1998.

26. Islaih M, Halstead BW, Kadura IA, Li B, Reid-Hubbard JL, Flick L, Altizer JL, Thom Deahl J, Monteith DK, Newton RK and Watson DE: Relationships between genomic, cell cycle and mutagenic responses of TK 6 cells exposed to DNA damaging chemicals. Mutat Res 578: 100-116, 2005.

27. Elkon R, Rashi-Elkeles S, Lerenthal Y, Linhart C, Tenne T, Amariglio N, Rechavi G, Shamir R and Shiloh Y: Dissection of a DNA-damage-induced transcriptional network using a combination of microarrays, RNA interference and computational promoter analysis. Genome Biol 6: R43.1-R43.8, 2005.

28. Amundson SA, Bittner M, Meltzer P, Trent J, Fornace AJ Jr: Physiological function as regulation of large transcriptional programs: the cellular response to genotoxic stress. Comp Biochem Physiol B 129: 703-710, 2001.

29. Singh N, Ebrahimi FA, Gimelbrant AA, Ensminger AW, Tackett MR, Qi P, Gribnau J and Chess A: Coordination of the random asynchronous replication of autosomal loci. Nat Genet 33: 339-341, 2003 